\title{
PROFIL TINGKAT PEMAHAMAN KONSEP FISIKA GERAK LURUS DENGAN MODEL CONCEPTUAL UNDERSTANDING PROCEDURES
}

\author{
Ma'ruf', R A Lestari' \\ 1. Pendidikan Fisika, FKIP, Universitas Muhammadiyah Makassar, Jl. Sultan Alauddin \\ No.259 Makassar, 90221, Indonesia \\ 2. Pendidikan Fisika, FKIP, Universitas Muhammadiyah Makassar, Jl. Sultan Alauddin \\ No.259 Makassar, 90221, Indonesia \\ E-mail:maruf@unismuh.ac.id
}

\begin{abstract}
ABSTRAK
Penelitian ini merupakan penelitian true experimental design yang bertujuan untuk mengetahui tingkat pemahaman konsep fisika gerak lurus dengan menggunakan model conceptual understanding procedural. Populasi dalam penelitian ini adalah peserta didik kelas X MIA SMA Muhammadiyah Limbung yang berjumlah 60 orang yang terbagi dalam 2 kelas yaitu X MIA 1 dan X MIA 2. Instrumen penelitian yang digunakan adalah instrumen tes pemahaman konsep fisika dalam bentuk pilihan ganda sebanyak 35 nomor yang memenuhi kriteria valid. Dari hasil penelitian dapat disimpulkan bahwa profil tingkat kemampuan pemahaman konsep fisika gerak lurus peserta didik yang diajar dengan menggunakan model Conceptual Understanding Procedures (CUPs) dengan menggunakan metode eksperimen berada pada kategori sedang.
\end{abstract}

Kata kunci: conceptual understanding procedures, gerak lurus, pemahaman konsep

\section{ABSTRACT}

This research is a true experimental design study. The population in this study were 60th grade students of MIA Muhammadiyah Limbung High School which were divided into 2 classes, namely X MIA 1 and X MIA 2. The research instruments were physics concept understanding test instruments. The conclusion of his research was that the understanding of straight-motion physics concepts of students taught using the Conceptual Understanding Procedures (CUPS) model using the experimental method was in the middle category of understanding the straightmotion physics concepts of students taught with conventional learning models in the low category.

(kosong satu spasi tunggal $10 \mathrm{pt}$ )

Keywords: conceptual understanding procedures, straight motion, understanding concepts

DOI: http://dx.doi.org/10.15575/jtlp.v4i2.4534

Received: 18 April 2019 ; Accepted: 7 Agustus 2019; Published: 19 Agutsu 2019 


\section{PENDAHULUAN}

Pendidikan bukan hanya sebuah upaya transfer pengetahuan melainkan sebuah upaya yang dilakukan agar anak-anak berkembang sesuai dengan potensi yang dimilikinya (Bloom, Englehard, Furst, \& Hill, 1956). Berkenaan dengan hal tersebut, belajar bukan hanya sekedar menghafal informasi dan rumus-rumus, melainkan bagaimana menggunakan informasi dan pengetahuan itu untuk mengasah pemahaman konsep peserta didik karena pendidikan sekarang ini yang dikenal dengan abad 21 berada dimana pengetahuan mengalami peningkatan yang luar biasa dan membutuhkan persaingan yang sangat pesat (Ma'ruf, Marisda, \& Handayani, 2019). Oleh karena itu, pendidikan menjadi semakin penting untuk menjamin peserta didik memiliki keterampilan belajar dan berinovasi, keterampilan menggunakan teknologi, dan media informasi, serta dapat bekerja, dan bertahan dengan menggunakan keahliannya tersebut (Satori, 2016).

Ilmu pengetahuan dianggap tidak sesuai dengan keadaan yaitu tiga alasan penting dimana alasan pertama adalah peserta didik bukan orang dewasa dalam bentuk mini, melainkan mereka adalah organisme yang sedang berkembang (Prasetyo, 2013). Alasan kedua, ledakan ilmu pengetahuan mengakibatkan kecenderungan setiap orang tidak mungkin dapat menguasai setiap cabang keilmuan. Begitu hebatnya perkembangan di era zaman sekarang yaitu apa yang dulu tidak pernah terbayangkan, sekarang menjadi kenyataan (Kementerian Pendidikan Nasional, 2005), dan alasan ketiga, penemuanpenemuan baru khususnya dalam bidang psikologi, mengakibatkan pemahaman baru terhadap konsep perubahan tingkah laku manusia (Nuraisyah, Samad, \& Maruf, 2015).

Ketiga konsep tersebut adalah: 1) keterampilan dan pengetahuan abad 21; (2) pendekatan saintifik; (3) penilaian autentik (Chu, Reynolds, Tavares, Notari, \& Lee, 2016). Berkenaan dengan hal tersebut peran guru disini juga sangat penting berdasarkan (Ahriana, Yani, \& Maruf, 2016). Fisika merupakan salah satu mata pelajaran di sekolah yang seringkali dianggap sulit oleh peserta didik. Namun tidak sedikit pula peserta didik yang menggemari mata pelajaran ini. Sebenarnya fisika bukan hanya sekedar kumpulan rumus yang tidak bermakna namun lebih dari itu fisika adalah sebuah fenomena yang terjadi pada alam ini yang diinterpretasikan dengan Bahasa matematika. Dimana rumus yang dihasilkan tersebut dapat dilogikakan dengan pemikiran sederhana yang tidak harus dihapal namun sangat perlu untuk dipahami. Pemahaman konsep fisika adalah dasar bagi peserta didik untuk membangun kemampuan pemecahan masalah fisika. Sebagian besar konsep-konsep fisika merupakan konsep-konsep yang abstrak dan bahkan mereka sendiri tidak mengenali konsep-konsep kunci ataupun hubungan antara konsep yang diperlukan untuk memahami konsep tersebut sehingga peserta didik tidak dapat membangun pemahaman konsep yang fundamental pada awal mereka belajar fisika (Syamsidar, Maruf, \& Hustim, 2018).

Untuk menguatkan pemahaman peserta didik terhadap mata pelajaran fisika, maka tidak boleh monoton terhadap penyampaian teori saja kepada mereka melainkan mengasah pengetahuan peserta didik dengan mengaitkan konsep fisika dengan kehidupan sehari-hari dengan kata lain memberikan penjelasan yang sederhana kepada peserta didik. Pemahaman konsep yang diperoleh dengan cara mengkonstruksi pemahaman lebih baik dibandingkan dengan pemahaman yang diperoleh secara informatif pada kegiatan ceramah (Ariansyah, Khaeruddin, \& Maruf, 2017)

\section{METODE PENELITIAN}

Rancangan Penelitian yang digunakan adalah jenis penelitian yaitu True-Eksperimental Design (Eksperimen Sebenarnya) dengan desain 
penelitian yang digunakan adalah The PosttestOnly Kontrol Design (Creswell, 2008). Terdapat dua kelompok yang dipilih secara randomisasi, dimana setiap kelompok diberikan postest untuk menentukan kelas eksperimen dan kelas kontrol (Pratiwi \& Muslim, 2016). Dimana kelas eksperimen diberi perlakuan dengan menerapkan model pembelajaran CUPs dengan metode eksperimen dan kelas kontrol diberi perlakuan dengan menerapkan model pembelajaran konvensional metode ceramah tanya jawab. Desain penelitian ini menggunakan The Posttest-Only Control Group Design.

Variabel penelitian pada penelitian yang dilakukan adalah variabel bebas dan variabel terikat. Variabel bebas dalam penelitian ini adalah model Conceptual Understanding Procedure (CUPS) dengan metode eksperimen. Variabel terikat penelitian ini adalah pemahaman konsep peserta didik.

Populasi dalam penelitian ini adalah seluruh peserta didik kelas X di SMA Ajaran 2018/2019 yang berjumlah 60 orang. Sampel dalam penelitian ini sama dengan jumlah populasi penelitian yaitu 60 orang yang terbagi menjadi 2 bagian, masing-masing memiliki 30 orang dalam satu kelas X di SMA Muhammadiyah Limbung. Adapun teknik pengambilan sampel yang digunakan dalam penelitian ini adalah teknik Simple Random Sampling untuk menentukan kelas yang menjadi Kelas Kontrol dan Kelas Eksperimen. Dimana kelas X MIA 1 adalah Kelas Kontrol dan X MIA 2 adalah kelas Eksperimen (Maruf, 2018).

Instrumen Penelitian yang digunakan berupa Tes Pemahaman Konsep. Tes disusun dalam bentuk soal pilihan ganda dengan materi fisika yang digunakan untuk mengukur pemahaman konsep fisika peserta didik.

Tabel 1. Pembagian Jumlah Soal Berdasarkan Indikator Pemahaman Konsep sebelum validasi

\begin{tabular}{|c|c|c|c|}
\hline No. & Indikator & $\begin{array}{c}\text { Sub } \\
\text { Indikator }\end{array}$ & No. Soal \\
\hline \multirow{3}{*}{1} & \multirow{3}{*}{ Translasi } & $\begin{array}{l}\text { Menerjema } \\
\text { hkan }\end{array}$ & $\begin{array}{c}16,19,37,47,48 \\
49,57\end{array}$ \\
\hline & & $\begin{array}{l}\text { Menggamb } \\
\text { arkan }\end{array}$ & $2,26,35,39$ \\
\hline & & $\begin{array}{l}\text { Menguraik } \\
\text { an }\end{array}$ & $\begin{array}{c}23,27,31,46,52 \\
53,54,55,60\end{array}$ \\
\hline \multirow{3}{*}{2} & \multirow{3}{*}{ Interpretasi } & $\begin{array}{l}\text { Menggamb } \\
\text { ar Grafik }\end{array}$ & $15,33,34,43$ \\
\hline & & $\begin{array}{l}\text { Menafsirka } \\
\mathrm{n}\end{array}$ & $\begin{array}{c}1,3,5,8,11,12 \\
30,38\end{array}$ \\
\hline & & $\begin{array}{l}\text { Mengidenti } \\
\text { fikasi }\end{array}$ & $\begin{array}{c}4,10,24,25,29 \\
32,36,44\end{array}$ \\
\hline \multirow{3}{*}{3} & \multirow{3}{*}{ Ekstrapolasi } & $\begin{array}{l}\text { Meramalka } \\
\mathrm{n}\end{array}$ & $9,14,20,42,45$ \\
\hline & & $\begin{array}{l}\text { Memperkir } \\
\text { akan }\end{array}$ & $\begin{array}{c}6,7,13,17,18 \\
41,51,58,59\end{array}$ \\
\hline & & $\begin{array}{l}\text { Menyimpul } \\
\text { kan }\end{array}$ & $\begin{array}{c}21,22,28,40,50, \\
56\end{array}$ \\
\hline
\end{tabular}

Teknik pengumpulan data melalui metode wawancara dilakukan peneliti saat melakukan observasi awal. Narasumber pada kegiatan wawancara adalah guru mata pelajaran fisika. Kegiatan wawancara bertujuan untuk memperoleh informasi tentang respon peserta didik pada saat pembelajaran fisika. Wawancara yang dilakukan berupa wawancara tidak terstruktur. Peneliti memberikan pertanyaanpertanyaan lisan kepada narasumber tentang hal yang berkaitan dengan kegiatan pembelajaran dan penelitian. Metode tes digunakan untuk mengetahui pemahaman konsep Gerak Lurus pada materi fisika kelas X. Tes yang diberikan mencakup aspek kognitif yang mencakup pemahaman konsep dengan indikator pemahaman translasi (penerjemahan), interpretasi (penafsiran) dan ekstrapolasi (makna yang terkandung) (Jackson, 2009).

Teknik analisis data yakni analisis statistik deskriptif, pada analisis ini digunakan skor rata-rata, standar deviasi, skor tertinggi (maksimum), skor terendah (minimum), serta distribusi frekuensi hasil belajar tes pemahaman konsep fisika peserta didik dalam beberapa indikator pemahaman 
konsep yang diteliti. Analisis statistik inferensial yang terdiri dari uji normalitas digunakan untuk mengetahui apakah data yang dianalisis berdistribusi normal atau tidak. Uji ini diterapkan pada kedua kelas yang telah dipilih sebelumnya sebagai kelas eksperimen dan kelas kontrol. Uji kesamaan varians dilakukan untuk mengetahui apakah keadaan kelas eksperimen dan kelas kontrol memliki varians yang sama atau tidak, dan uji hipotesis yaitu untuk mengetahui perbedaan pemahaman konsep peserta didik kelas eksperimen lebih baik daripada peserta didik kelas kontrol, maka dilakukan pengujian dengan menggunakan uji t dua pihak (Maruf, 2018).

\section{HASIL DAN PEMBAHASAN}

\section{Analisis statistik deskriptif}

Tabel 2. Statistik Skor Pemahaman Konsep Peserta Didik Kelas X SMA Muhammadiyah Limbung

\begin{tabular}{lcc}
\hline \multirow{2}{*}{ Statistik } & \multicolumn{2}{c}{ Nilai Statistik } \\
\cline { 2 - 3 } & Eksperimen & Kontrol \\
\hline Subjek & 30 & 30 \\
\hline Standar Deviasi & 4.340 & 3.740 \\
\hline Variansi & 18.830 & 13.960 \\
\hline Skor tertinggi & 27 & 23 \\
\hline Skor terendah & 12 & 8 \\
\hline Rentang data & 15 & 15 \\
\hline $\begin{array}{l}\text { Banyak kelas } \\
\text { interval }\end{array}$ & 6 & 6 \\
\hline $\begin{array}{l}\text { Panjang kelas } \\
\text { interval }\end{array}$ & 2 & 2 \\
\hline
\end{tabular}

\begin{tabular}{lcc}
\hline \multirow{2}{*}{ Statistik } & \multicolumn{2}{c}{ Nilai Statistik } \\
\cline { 2 - 3 } & Eksperimen & Kontrol \\
\hline Skor rata-rata & 19.000 & 13.900 \\
\hline Skor minimum & 0 & 0 \\
\hline Skor ideal & 35 & 35 \\
\hline
\end{tabular}

Dari tabel tersebut dapat dilihat bahwa hasil tes pemahaman konsep peserta didik yang diperoleh dari kelas eksperimen dan kelas kontrol sedikit berbeda dengan perbedaan hingga 4 skor. Jika skor hasil pemahaman konsep peserta didik pada kelas X2 (Kelas Eksperimen) dan kelas X1 (Kelas Kontrol) SMA Muhammadiyah Limbung dikategorisasikan dalam skala lima yaitu sangat rendah, rendah, sedang, tinggi, dan sangat tinggi, maka akan diperoleh hasil seperti pada tabel berikut:

Tabel 3. Statistik Skor Pemahaman Konsep Peserta Didik Kelas X SMA Muhammadiyah Limbung

\begin{tabular}{ccccccc}
\hline \multirow{2}{*}{$\begin{array}{c}\text { N } \\
\mathbf{0}\end{array}$} & \multirow{2}{*}{$\begin{array}{c}\text { Interval } \\
\text { skor }\end{array}$} & Kategori & & \multicolumn{3}{c}{ (fi) } \\
\cline { 5 - 6 } & & & & $\begin{array}{c}\text { Eksperim } \\
\text { en }\end{array}$ & $\begin{array}{c}\text { Kontr } \\
\text { ol }\end{array}$ \\
\hline 1 & 29 & - & 3 & $\begin{array}{c}\text { Sangat } \\
\text { Tinggi }\end{array}$ & 0 & 0 \\
\hline 2 & 22 & - & 2 & Tinggi & 11 & 1 \\
\hline 3 & 15 & - & 2 & Sedang & 14 & 15 \\
\hline 4 & 8 & - & 1 & Rendah & 5 & 14 \\
\hline 5 & 0 & - & 7 & $\begin{array}{c}\text { Sangat } \\
\text { Rendah }\end{array}$ & 0 & 0 \\
\hline
\end{tabular}


Rata-rata peserta didik yang paling tinggi persentase untuk menjawab benar pada kelas eksperimen mampu menjawab dengan baik soal yang termasuk dalam indikator ekstrapolasi namun sebaliknya pada kelas kontrol memiliki kesulitan dalam menjawab soal yang termasuk dalam indikator pemahaman ekstrapolasi. Hal ini disebabkan karena pemahaman ekstrapolasi adalah kemampuan untuk memberikan gambaran akan sesuatu hal berdasarkan kejadian yang berhubungan pada data. Secara rinci dari pencapaian indikator pemahaman konsep dapat dilihat pada gambar 1.

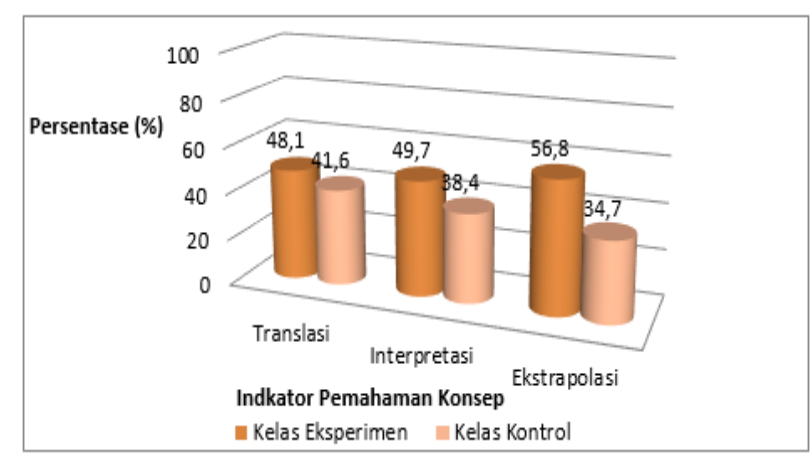

Gambar 1. Persentase indikator pemahaman konsep

\section{Analisis statistik inferensial}

Tabel 4. Hasil uji normalitas

\begin{tabular}{lccc}
\hline & $\chi^{2}$ hitung & $\chi^{2}$ tabel & Keterangan \\
\hline Eksperimen & 2,882 & 7,810 & Normal \\
\hline Kontrol & 1,182 & 7,810 & Normal \\
\hline
\end{tabular}

Berdasarkan tabel tersebut, terlihat bahwa untuk setiap kelas diperoleh nilai $\chi 2$ hitung < nilai $\chi 2$ tabel. Sehingga dapat disimpulkan bahwa data pemahaman konsep fisika peserta didik kelas X MIA di SMA Muhammadiyah Limbung berasal dari populasi yang berdistribusi normal.

Uji kesamaan varians atau homogenitas varians digunakan untuk mengetahui beberapa varian populasi adalah sama atau tidak. Pengujian homogenitas dilakukan dengan menggunakan aplikasi Ms. Excel 2010, hasil dari pengujian homogenitas dengan uji $F$ yaitu F_hitung dibandingkan dengan $\mathrm{F}_{-}$tabel. Diperoleh $\mathrm{F}_{-}$tabel $=F_{-}((1-\alpha ; d k 1 ; d k 2))=F_{-}((1-0,05 ; 29 ; 29))=1,850$ dan pada F_hitung yaitu 1,480. Adapun kriterianya yaitu jika F_hitung < F_tabel, berarti varians homogen, sebaliknya jika F_hitung > F_tabel, maka varians tidak homogen. Kriteria yang terpenuhi adalah $F_{-}$hitung $<F_{-}$tabel yaitu $1.480<1.850$, maka kelompok tersebut dikatakan varians homogen.

Tabel 5. Hasil analisis uji-t

\begin{tabular}{cc}
\hline \multicolumn{2}{c}{ Kelas } \\
\hline Eksperimen & Kontrol \\
\hline$n_{1}=30$ & $n_{2}=30$ \\
\hline $\bar{X}_{1}=19,000$ & $\bar{X}_{2}=13,900$ \\
\hline$S_{1}=4,340$ & $S_{2}=3,740$ \\
\hline
\end{tabular}

Dapat dilihat bahwa skor rata-rata kelas eksperimen adalah 19,000 dan standar deviasi 4,340 dengan jumlah peserta didik sebanyak 30 orang sedangkan pada kelas kontrol skor ratarata adalah 13,900 dan standar deviasi 3,740 dengan jumlah peserta didik sebanyak 30 orang. harga thitung berada pada daerah penolakan, dengan taraf nyata $\alpha=0,05$. Dengan demikian Ho ditolak dan hipotesis $\mathrm{H} 1$ diterima. Hal ini berarti bahwa terdapat perbedaan pemahaman konsep peserta didik yang diterapkan dan tidak diterapkan dengan menggunakan model pembelaajaran Conceptual Understanding Procedures (CUPs) dengan metode eksperimen dalam meningkatkan pemahaman konsep peserta didik sehingga dapat dikemukakan bahwa terdapat pengaruh pemahaman konsep fisika peserta didik yang diterapkan model pembelajaran Conceptual Understanding Procedures (CUPs) dengan metode eksperimen di kelas yang diterapkan dan tidak diterapkan pada kelas X MIA SMA Muhammadiyah Limbung. Berdasarkan analisis yang telah dilakukan dengan menggunakan analisis statistik deskriptif dan inferensial, maka hasil yang diperoleh pada analisis deskriptif menunjukkan bahwa hasil tes pemahaman konsep fisika peserta didik di SMA Muhammadiyah memperlihatkan perbandingan skor pemahaman konsep fisika peserta didik yang diterapkan model pembelajaran Conceptual Understanding Procedures (CUPs) dengan metode eksperimen 
berada pada kategorisasi sedang sedangkan hasil skor pemahaman konsep fisika peserta didik yang diterapkan pembelajaran konvensional tergolong kedalam kategorisasi rendah. Hal ini memberikan indikasi bahwa pemahaman konsep peserta didik di kelas eksperimen yang diterapkan model pembelajaran Conceptual Understanding Procedures (CUPs) dengan metode eksperimen dengan lebih besar pengaruhnya dibandingkan dengan kelas kontrol yang diterapkan pembelajaran konvensional. Hal ini disebabkan karena peserta didik pada saat proses pembelajaran sangat antusias pada fase dimana mereka melakukan percobaan dan melakukan diskusi pada akhir pembelajaran untuk menyampaikan dan menarik kesimpulan dari percobaan yang dilakukan serta bekerja sama dalam menyelesaikan beberapa soal yang ada pada LKPD. Sedangkan untuk kelas kontrol skor indikator pemahaman konsep yang terendah yaitu indikator "ekstrapolasi". Hal ini disebabkan karena dalam soal yang termasuk kategori pemahaman ekstrapolasi adalah soal yang berhubungan dengan kemampuan untuk menyimpulkan dan memprediksikan konsekuensi dari tindakan yang diberikan ataupun yang telah ditentukan.

Hasil analisis selanjutnya adalah analisis inferensial yang pertama untuk uji normalitas yang menunjukkan bahwa kedua kelas tersebut berasal dari populasi yang berdistribusi normal. Analisis kedua yaitu uji homogenitas yang menunjukkan bahwa kelas tersebut berasal dari kelas yang homogen, dan analisis yang ketiga yaitu uji hipotesis yang menunjukkan bahwa rata-rata skor populasi hasil tes pemahaman konsep fisika peserta didik kelas X MIA 2 yang diterapkan dengan model pembelajaran Conceptual Understanding Procedures (CUPs) dengan metode eksperimen tidak sama dengan rata-rata skor populasi hasil tes pemahaman konsep fisika peserta didik kelas X MIA 1 yang diterapkan dengan pembelajaran model konvensional yang menunjukkan adanya pengaruh pembelajaran fisika terhadap pemahaman konsep fisika dengan menggunakan model pembelajaran Conceptual Understanding Procedures (CUPs) dengan metode eksperimen
Hal tersebut memberi indikasi bahwa dengan pembelajaran fisika model pembelajaran Conceptual Understanding Procedures (CUPs) dengan metode eksperimen merupakan salah satu pembelajaran fisika yang efektif digunakan untuk mencapai hasil belajar fisika.

\section{KESIMPULAN}

Adapun kesimpulan dari hasil penelitian ini adalah sebagai berikut:

1. Pemahaman konsep fisika peserta didik yang diterapkan model Conceptual Understanding Procedures (CUPs) dengan menggunakan metode eksperimen ditunjukkan dengan persentase rata-rata hasil posttest (tes akhir) berada dalam kategori sedang.

2. Pemahaman konsep fisika peserta didik yang diaterapkan dengan model pembelajaran konvensional ditunjukkan dengan persentase rata-rata hasil posttest (tes akhir) berada dalam kategori rendah.

3. Terdapat perbedaan hasil belajar fisika pada peserta didik yang diajar dengan model pembelajaran Conceptual Understanding Procedures (CUPs) dengan metode eksperimen dengan peserta didik yang tidak diajar dengan menggunakan model Conceptual Understanding Procedures (CUPs) dengan menggunakan metode eksperimen 


\section{DAFTAR PUSTAKA}

Ahriana, Yani, A., \& Maruf, U. M. M. (2016). Studi Analisis Hubungan Antara Self Efficacy dengan Hasil. Jurnal Pendidikan Fisika, 4(2), 223-238.

Ariansyah, Khaeruddin, \& Maruf, U. M. M. (2017). Upaya Meningkatkan Hasil Belajar Fisika Melalui Pembelajaran Kontekstual Pada Siswa Kelas VII SMP Aisyiyah. Jurnal Pendidikan Fisika, 3, 91-104.

Bloom, B. S., Englehard, M. D., Furst, E. J., \& Hill, W. H. (1956). Taxonomy of educational objectives: The classification of educational goals: Handbook I, cognitive domain. London, 1-207.

Chu, S. K. W., Reynolds, R. B., Tavares, N. J., Notari, M., \& Lee, C. W. Y. (2016). 21st century skills development through inquiry-based learning: From theory to practice. 21st Century Skills Development Through Inquiry-Based Learning: From Theory to Practice, 1-204.

Creswell, J. W. (2008). Educational Research. Animal Genetics (Vol. 39).

Jackson, S. L. (2009). Research Methods and Statistics: A Critical Thinking Approach. Library of Congress, 449.

Kementerian Pendidikan Nasional. (2005). Standar Nasional Pendidikan. Kemendiknas (Vol. 9).

Ma'ruf, M., Marisda, D. H., \& Handayani, Y. (2019). The basic physical program based on education model online assisted by alfa media to increase creative thinking skills. Journal of Physics: Conference Series, 1157, 032068.

Maruf, U. M. M. (2018). Statistika Dasar Untuk Penelitian Pendidikan Fisika. Lembaga Perpustakaan dan Penerbitan Universitas Muhammadiyah Makassar.
Nuraisyah, Samad, A., \& Maruf, U. M. M. (2015). Upaya Meningkatkan Hasil Belajar Fisika Melalui Model Pemecahan Masalah ( Problem Solving ). Jurnal Pendidikan Fisika, 3(3), 270-278.

Prasetyo, Z. K. (2013). Konsep dasar pendidikan ipa. Universitas Negeri Yogyakarta.

Pratiwi, T. R., \& Muslim. (2016). using integrated type on science learning for improving junior high school students critical thinking skills. Jurnal Pendidikan Fisika Indonesia, 12(1), 33-40.

Satori, D. (2016). Pengawasan dan Penjaminan Mutu Pendidikan. Alfabeta Bandung.

Syamsidar, Maruf, U. M. M., \& Hustim, R. (2018). Pembelajaran Fisika Berbasis Cone of Experience Edgar Dale. Jurnal Pendidikan Fisika, 6, 1-12. 